\title{
Book Review: The Rise to Market Leadership
}

\author{
Edited by Malerba, F., Mani, S., and Adams, P. (2017)-The Rise to Market Leadership-Published \\ by E-Elgar
}

Mohamed Buheji $1^{1}$

${ }^{1}$ International Institute of Inspiration Economy, Bahrain

Correspondence: International Institute of Inspiration Economy, Bahrain. E-mail: buhejim@gmail.com

Received: January 16, 2018

Accepted: January 30, $2018 \quad$ Online Published: February 8, 2018

doi:10.5430/ijba.v9n2p44

URL: https://doi.org/10.5430/ijba.v9n2p44

\section{Introduction to the Importance for Reviewing This Book}

Development has been happening the last two decades and specially the beginning of the $21^{\text {st }}$ century shows that the emerging economies are going to change the formula of the current market dominated leadership. Certainly, many emerging economies as the BRICS countries is a must watch and explore markets from the perspective of being economies that having the strong diversified mix to make more sustainable as the developed countries markets and even more. The work of Malerba et al. (2017) team is highly important since it reflects not only the literature review but also the actual observations of the history of development of the BRICS countries, which resembled by China, India and Brazil. In fact, the book also shows the best practices in how did these new market leaders emerge and become key players in their respective industries. This review is considered of importance since it shows a model for other countries and how to manage the high industries risk and still manage to create market development. The review shows that there are similar industries as automotive, pharmaceutical and ICT industries which can contribute to the success of the developing countries and enable them to become market leaders too. The researchers were very focused on defining market leadership from the following three angles mainly: domination of local market, global reach and the innovative capabilities and capacity of the production or the processes.

\section{Reflections on the Book}

The Rise to Market Leadership is not only an academic book, but also a comparative manual of the best practices that make any developing or even under-developed country to follow the top three BRICS countries towards sustained development and not only growth. The book is a mix between firm leadership that lead to countries market leadership. The book has been precise in selecting the firms that have new technological development or products with hi-tech processes, or that require many associated clusters. A common framework of analysis brings together the leadership factors that differentiate the firms under focus and how they help to develop their countries market leadership in these sectors.

The book brilliantly links the role of entrepreneurship in raising the knowledge and learning capabilities lead to country's competitiveness and development even in the global innovation index, even though this is not explicitly stated. Therefore, this book can be a good reference for students, researcher and even practitioners whom are interested in emerging economies, industrial developments, countries competitiveness, national strategies developers and macro- innovation management experts. This book can also be a very good companion for those monitoring the democratic economies as knowledge economy, innovation economy and learning economy which clearly can be traced in the case studies presented.

The framework of the book which contains both national and sectoral innovation and it illustrate how reach market leadership whether for a firm or a country through main processes of continuous learning and capability building. The framework is unique as says simply that regardless of the government policies and systems and regardless of the market structure, still this framework can work effectively to create the necessary transformation.

The book is highly those hands-on field researchers, practitioners and even consultants since it illustrates in detail tools that differentiate these firms to be a source for developing their countries such as using reverse engineering, in-house technology development, knowledge expertise capturing and effective partnership with higher education 
institutes. The Malerba et al. (2017) team were also successful in focusing in the different knowledge transfer techniques through different level of partnership and joint ventures with similar competing firms. This intensive knowledge work is highly recommended for those working in setting countries strategies in relevance to research and development clusters as it give a great detail how three emerging economies have created high end products as a result of the R\&D focused efforts.

\section{Recommendations on the Book}

One of the recommendations for the Malerba et al. (2017) team is to use more the word "development" than "growth", to resemble the differentiated leadership. It is believed that this book did not only address the research question of how firms rise in market leadership but also how do countries can do a pragmatic shift from being developing to be developed countries. I believe that the authors can easily re-arrange their future editions in relevance to titles as case studies for countries development, macro-innovation, constructs of national competitiveness, competitive national clusters, national strategies development, towards innovative economies, transformation from emerging to developed economies.

Malerba et al. (2017) toke a bit risky decision in having the clusters as part of the sectoral variables, however firm level factors are very clear. In future editions, it would be worthwhile to concentrate on clusters that can be developed by these firms. Also, the authors show how the national institutions including government, financial and educational institutions would help in developing the economy through the different clusters.

The book is full of well laid cases profiles for each industry that help to develop the market leadership for the three countries, China, India and Brazil. However, the authors might want to do a comparative table that would require differentiation and the advantages and disadvantage of each these cases. One has to mention though that the book is unique in illustrating the "sources of inspiration" that influenced these industries and their countries to lead over the years.

Despite one could see that all the three chosen sectors, i.e. the Automobile, Pharmaceutical and ICT does not complement each other, it the complexity of the supply chain of these sectors is what makes them coincide together in creating a cluster that support the country's development. All these three industries use many suppliers to deliver their final products and also support directly and indirectly the development of entrepreneurs and small and medium enterprises (SME's). The uniqueness of these three industries is that they need multi-disciplined workers and human capital dependent even if highly automated. The book is highly beneficial for those who focus on capacity building and have provided during the presentation of the case studies great practical tools that helped these industries to lead in their sector.

Finally, as an Inspiration, Resilience and Youth Economy Researcher I believe this book managed successfully to give in its comprehensive review a clear picture of what make the Indian, Chinese and Brazilian economic evolution more robust in relevant to depth of development and high possibility of coming competitiveness of the contributing industries reviewed. Each page carries lots of good practices that we can apply to other developing countries. It is a highly professional and not only academic book that carries a great deal of the symphony of the interplay between the rising firms and innovation systems they managed to imbed in the cycle of their countries' economies. Surely, something we need to learn from humbly. 